
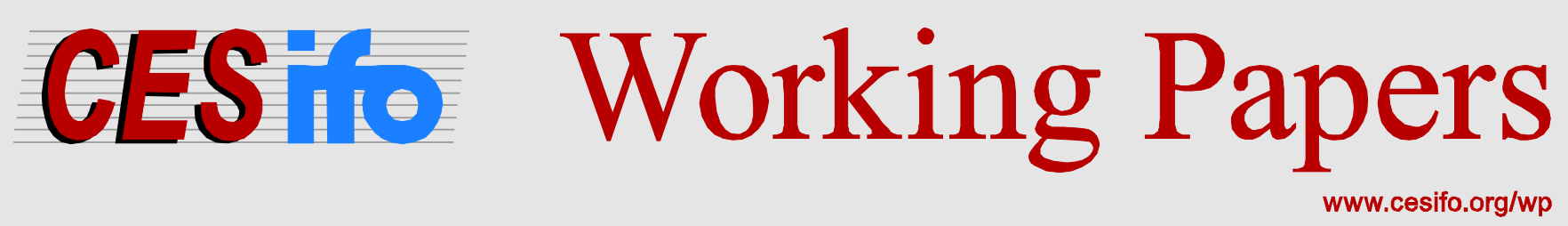

\title{
Carbon Tax Burdens on Low-Income Households: A Reason for Delaying Climate Policy?
}

\author{
Ian Parry \\ CESIFO WORKING PAPER NO. 5482 \\ CATEGORY 1: PUBLIC FinANCE \\ August 2015 \\ An electronic version of the paper may be downloaded \\ - from the SSRN website: Www.SSRN.com \\ - from the RePEc website: Www.RePEc.org \\ - from the CESifo website: www.CESifo-group.org/wp
}




\title{
Carbon Tax Burdens on Low-Income Households: A Reason for Delaying Climate Policy?
}

\begin{abstract}
This paper discusses techniques for measuring the incidence of carbon taxes across different household income groups and provides some cross-country estimates of these effects for selected advanced countries. The general message of this paper is that distributional concerns should not necessarily hold up carbon pricing. Energy price impacts may be less regressive than often supposed and there are ample opportunities in advanced countries for adjusting tax and benefit schedules to alter the overall incidence of a carbon tax reform. Insofar as possible however, using carbon tax revenues in ways that enhance economic efficiency is critical for containing overall costs to the economy.
\end{abstract}

JEL-Code: H220, Q520, Q540, Q580.

Keywords: carbon tax, distributional incidence, fiscal reform, climate change, revenue recycling.

\author{
Ian Parry \\ Fiscal Affairs Department \\ International Monetary Fund (IMF) \\ 700 19th Street, N.W. \\ USA - 20431 Washington DC \\ iparry@imf.org
}

I am grateful to Steve Clark, Terry Dinan, Tarun Narasimhan, and Ruud de Mooij for help with this paper. 


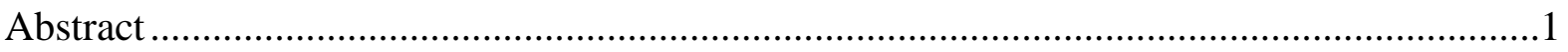

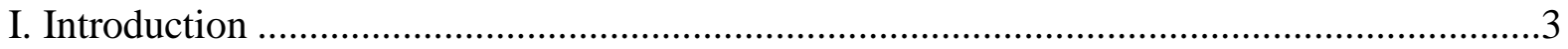

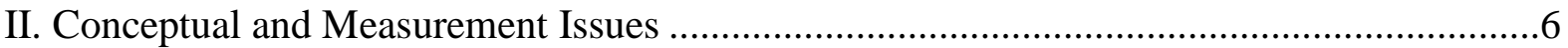

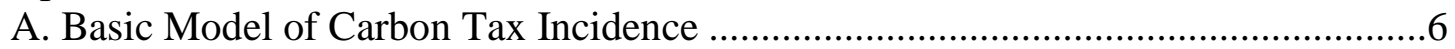

B. Measurement Issues: A Quick Look ..............................................................

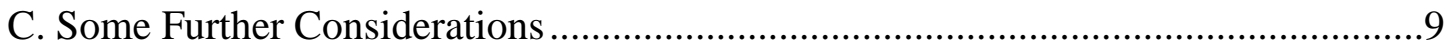

D. Implications and Importance of Revenue Recycling ...........................................

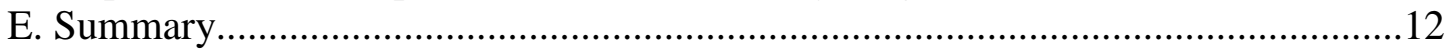

III. Incidence across Advanced Countries: A Broad Picture ...............................................13

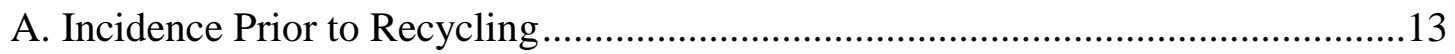

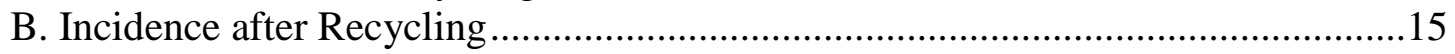

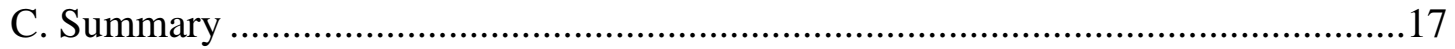

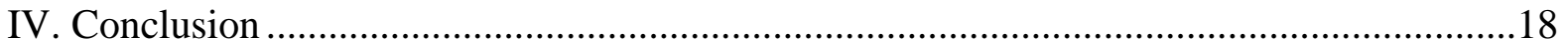

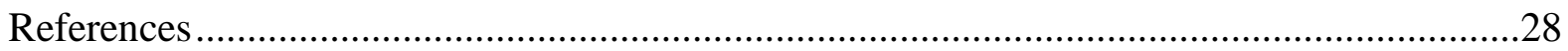

\section{FIGURES}

1. Burden of a Fuel Tax for a Household Group ..............................................................21

2. Illustrative Cost of a Carbon Tax, with and without Revenue Recycling .........................21

3. First-Order Burden from a $\$ 35$ per ton $\mathrm{CO}_{2}$ Tax, Selected Countries................................22

4. Increase in Energy Prices for a $\$ 35$ per ton $\mathrm{CO}_{2}$ Tax, Selected Countries ...........................23

5. Direct and Indirect Burden of a Carbon Tax by Income Quintile .....................................24

6. Carbon Tax Incidence by Income Quintiles Prior to Revenue Recycling ..........................25

7. Burden of Higher Household Energy Prices that could be Offset ....................................26

8. Share of Federal Taxes by Income Quintile, United States .............................................27

\section{BOXES}

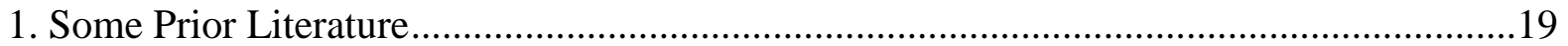

2. Carbon Tax Incidence in Developing Countries........................................................20 


\section{INTRODUCTION}

Without strong measures to mitigate carbon dioxide $\left(\mathrm{CO}_{2}\right)$ and other greenhouse gases, global temperatures are projected to rise by around $3-4{ }^{\circ} \mathrm{C}$ over pre-industrial levels by the end of this century, with serious risks of catastrophic outcomes. ${ }^{2}$

Carbon taxes, or similar pricing instruments ${ }^{3}$, should be front and center in climate change mitigation. These instruments:

- exploit the full range of emissions mitigation opportunities (shifting to cleaner fuels, reducing energy use, etc.), so long as they are directly targeted at emissions; ${ }^{4}$

- achieve $\mathrm{CO}_{2}$ reductions at lowest cost to the economy, so long as revenues are used productively, most obviously (for advanced countries) to lower the burden of broader taxes on labor and capital;

- promote only those emissions reductions for which environmental benefits outweigh the costs, so long as tax rates are aligned with (albeit contentious) environmental damage assessments;

- can involve a practical extension of motor fuel excises (long established in most countries and among the easiest of taxes to administer) to other fuel products; ${ }^{5}$

- are in many countries' own self-interest due to domestic environmental co-benefits (e.g., reduced air pollution deaths); ${ }^{6}$ and

- require international coordination over one main parameter (a price floor).

While carbon pricing schemes are emerging in many regions and countries (World Bank 2014, Figure 1), little over one-tenth of global greenhouse gas emissions in 2013 were formally priced, and current prices are generally far below what is needed. ${ }^{7}$ Clearly the politics of carbon taxes are not easy, and at the heart of this is the potential impact on vulnerable (or politically influential) groups. Most debate has surrounded low-income

\footnotetext{
${ }^{2}$ Including much higher warming due to feedbacks in the climate system, dramatic sea level rises from collapsing ice sheets, dramatic local climate change from changing ocean currents, etc.

${ }^{3}$ The discussion here focuses on carbon taxes, though the distributional incidence of their emissions trading analogs (with allowance auctions) is equivalent for the same emissions coverage, prices, and revenue use.

${ }^{4}$ For the United States a carbon tax is about five times as effective at reducing $\mathrm{CO}_{2}$ as a comparable tax on electricity or incentive for renewable power generation (Parry et al. 2014a, Figure 3.1).

${ }^{5}$ In the United States, a tax on the carbon content of fossil fuels need only involve monitoring around 1,5002,000 taxpayers (e.g., Calder 2015).

${ }^{6}$ See, for example, Parry et al. (2014b).

${ }^{7}$ Prices in the largest program, the EU Emissions Trading Scheme, have been below the equivalent of US \$10 per ton in recent years, substantially less than estimated environmental damages, or levels (if globally applied) consistent with aggressive long-run climate stabilization (see below).
} 
households (the focus of this paper) as well as trade-exposed, energy-intensive firms (which is beyond the scope). ${ }^{8}$

Having a sense of the distributional incidence of carbon taxes across households is critical to inform policy dialogue and aid in designing accompanying measures-either to protect low income households and/or alter the overall distributional equity of the fiscal reform. Policies perceived as broadly fair in this regard are not only desirable for their own sake (more so, given recent trends towards greater inequality in after-tax incomes-see Immervoll and Richardson 2011) but also may have a better chance of being enacted and sustained.

This paper takes stock of methods for estimating household incidence and applies them (albeit crudely) across advanced countries (where data is more available)—Box 1 provides some discussion of the (rather limited) previous literature on carbon tax incidence.

The main theme of the discussion is that, for several reasons, distributional concerns should not hold up carbon taxes:

- Carbon taxes are less regressive (disproportionately burdening low-income groups) than they might first appear. Although the poor generally spend a greater share of their annual income on electricity:

$>$ this is less true for transportation and heating fuels, and other consumer products whose prices increase indirectly from higher energy costs;

$>$ regressive effects are less pronounced when incidence is measured against household consumption (arguably a better measure of household wellbeing than income); and

$>$ some cross-country calculations suggest the incidence of carbon taxes can be anything from moderately regressive, to proportional, to moderately progressive.

- Undercharging for carbon damages is a highly inefficient way to help low-income households, as the vast majority of benefits (typically around 90 percent) leak away to higher income groups. Targeted measures are much more effective.

- There are ample opportunities for compensating low-income households in advanced countries through targeted fiscal/spending adjustments and combining carbon taxes with other progressive measures (e.g., reducing tax preferences for the wealthy), though the specifics will vary across countries (with the extent of inequality, parameters of the fiscal system, etc.). The focus should be the distributional impact of the whole policy package, not just the component that raises energy prices.

\footnotetext{
${ }^{8}$ For some discussion of competitiveness impacts, and transitory policies to address them, see, for example, Böhringer et al. (2012) and Fischer et al. (2015).
} 
A second theme of the paper (though one already receiving much emphasis in the literature) is that diverting carbon tax revenues from the general budget for compensation involves significant costs. Reasonably accurate estimates of burdens on vulnerable groups are therefore important for gauging appropriate compensation levels. And, insofar as possible, compensation instruments that enhance economic efficiency (e.g., targeted tax cuts or tax credits that strengthen incentives for work effort) should be used over instruments that do not (e.g., transfer payments).

The paper is organized into two main parts. The first deals with conceptual and measurement issues, while the second gives some (very broad) quantitative sense of incidence effects of carbon taxes across advanced countries (prior to recycling) and discusses options for simultaneous adjustments to the broader tax/benefit system. The last section provides concluding remarks. 


\section{ConCEPTUAL AND MEASUREMENT IsSUES}

The economic burden or incidence of a tax refers to whose economic welfare is reduced by this tax and by how much. This is quite different from formal or legal incidence-for example, fuel suppliers may remit carbon tax payments to the government, but bear little incidence if the charge is mainly reflected in higher prices for fuel users. The point in the fossil fuel supply chain at which carbon taxes are levied is largely irrelevant for the ultimate incidence of the tax.

This section presents the most basic analytical model of carbon tax incidence, discusses the measurement of key factors determining incidence, considers some complicating factors, and emphasizes the importance of using carbon tax revenue efficiently.

\section{A. Basic Model of Carbon Tax Incidence}

Consider a static model with the following assumptions (which are relaxed later):

- the carbon tax burden is fully passed forward into consumer prices;

- co-benefits (e.g., better local air quality) from carbon pricing are ignored; and

- incidence is measured prior to adjustments in the broader tax/benefit system.

In this setting, carbon tax incidence for a particular household group reflects their loss of consumer surplus, aggregated across all consumer products whose prices rise in response to the higher energy costs caused by the carbon tax.

Consider first a tax on the carbon content of a single fuel, denoted by $X$, directly consumed by households (e.g., gasoline, residential natural gas). Households are classified into $i=1 \ldots N$ income groups, where $I_{i}$ (defined more carefully below) is average income for group $i$. The fuel demand curve for group $i$ (taken to be linear over the relevant range) is shown in Figure 1, where the height of this curve at any point reflects the benefit to fuel users from an extra unit of consumption.

The fuel supply curve is perfectly elastic (i.e., fuel is produced competitively under constant returns) with $p_{X 0}$ denoting the per unit production cost or supply price. As drawn in Figure 1 , there is no pre-existing fuel tax, so $p_{X 0}$ is also the initial (pre-carbon tax) price to fuel users (pre-existing taxes are discussed below). Initial fuel consumption for household group $i$ is $X_{i 0}$ and consumer surplus - benefits to fuel users (the area under the demand curve integrated between the origin and $X_{i 0}$ ) less payments to fuel suppliers - is area $a b c$.

Suppose a carbon tax is introduced, increasing the fuel user price to $p_{X 1}$, where $p_{X 1}-p_{X 0}$ equals the tax rate per ton of $\mathrm{CO}_{2}$ times the fuel's emissions factor $\left(\mathrm{CO}_{2}\right.$ per unit of $X$ ). Fuel consumption falls to $X_{i 1}$ and consumer surplus falls by trapezoid $e d b c$, consisting of the first order loss edfc, due to paying a higher price on consumption (the tax payment), plus $d b f$, or benefits from foregone consumption $X_{i 0}-X_{i 1}$ net of what households would have paid or that consumption. 
The consumer surplus loss or tax burden for group $i$, denoted $B_{i}$, can be written:

(1) $B_{i}=\left(p_{X 1}-p_{X 0}\right) X_{i 0}\left(1-\frac{X_{i 0}-X_{i 1}}{2 X_{i 0}}\right) \approx\left(p_{X 1}-p_{X 0}\right) X_{i 0}$

This approximation, equal to rectangle egbc in Figure 1, is reasonable for the relatively modest changes in fuel use from carbon taxes likely to be implemented in the near term. ${ }^{9}$

Expressing the burden relative to group i’s income gives:

(2) $\frac{B_{i}}{I_{i}} \approx \frac{\left(p_{X 1}-p_{X 0}\right)}{p_{X 0}} \frac{p_{X 0} X_{i 0}}{I_{i}}$

This is the proportionate fuel price increase (the same for all households) times group i's budget share for the fuel. In this highly simplified case, tax incidence is regressive if fuel budget shares are higher for lower income groups; proportional if all groups have the same budget share; and progressive if higher income groups have higher budget shares. Alternatively, $p_{X 0}$ could be cancelled from (2), but data at the household level is generally reported on product expenditures $\left(p_{X 0} X_{i 0}\right)$, rather than physical consumption units $\left(X_{i 0}\right)$.

More generally, a carbon tax directly increases consumer prices for several energy products (electricity, heating and transportation fuels) and indirectly for goods in general (by raising the costs of intermediate energy inputs). The above formula readily generalizes to the case of multiple consumer price rises, so the burden to income approximation is simply:

$$
\text { (3) } \frac{B_{i}}{I_{i}} \approx \sum_{j=1}^{M}\left(\frac{p_{X 1}^{j}-p_{X 0}^{j}}{p_{X 0}^{j}}\right)\left(\frac{p_{X 0}^{j} X_{i 0}^{j}}{I_{i}}\right)
$$

where superscript $j$ indexes a consumer product $j$, and there are $j=1 \ldots M$ product groupings. The price increase for a particular product like cars, for example, will reflect the $\mathrm{CO}_{2} \operatorname{tax}$ times embodied carbon- $-\mathrm{CO}_{2}$ emissions per vehicle from the electricity and fuels used in the manufacture of component parts and assembly.

For advanced countries (see below), carbon taxes appear regressive because lower income households have a relatively high propensity to spend out of current income and energy products tend to be, albeit weak, necessities, ${ }^{10}$ though incidence is less regressive when the full range of products whose prices increase are taken into account.

\footnotetext{
${ }^{9}$ For example, the approximation overstates the loss of consumer surplus by only 5 percent when fuel use is reduced by 10 percent.

10 Meta analyses by Espey (1998) and Espey and Espey (2004) put median income elasticities for transport fuels and electricity at 0.83 and 0.92 respectively in advanced countries, though there is considerable variation across studies. Unfortunately, not much is known about how income elasticities vary by income class, which would provide a more refined sense from this information of how budget shares for energy products vary across the income distribution.
} 


\section{B. Measurement Issues: A Quick Look}

Previous studies (like those in Box 1) have measured incidence effects of carbon taxes (or broader environmental/energy taxes), using formulas like that in equation (3), or more sophisticated versions of it (e.g., incorporating behavioral responses). Implementing (3) requires three main pieces of data: price impacts and, by household group, income, and product expenditures.

\section{Price Impacts}

Absolute price increases for energy products directly consumed by households are easily calculated by the tax rate times the $\mathrm{CO}_{2}$ emissions factors for the respective fuels. These factors are essentially fixed for motor fuels and natural gas, and vary very little across countries, ${ }^{11}$ though $\mathrm{CO}_{2}$ emissions rates per unit of electricity-available by country from the International Energy Agency (IEA) — obviously vary with a country's power generation fuel mix. Proportionate price increases can be obtained using baseline price data, which is available from IEA for advanced countries and estimated for other countries by Clements et al. (2013). Direct effects on energy prices account for around two-thirds of the total estimated burden of a carbon tax for the United States, and likely somewhat more than this for other advanced countries (see below).

Input/output tables can be used to estimate the indirect impacts of carbon taxes on the prices of other consumer products. These tables provide, for different industries, the value of outputs, for final and intermediate products, and inputs-both energy (fuels, electricity) and non-energy (labor, capital, raw materials, etc.). Dividing fuel and electricity purchases by fuel prices, and applying emissions factors, the embodied $\mathrm{CO}_{2}$ per $\$$ for each intermediate product, and ultimately each final product, can be inferred, and multiplied by the $\mathrm{CO}_{2}$ tax to give the proportionate price increases. ${ }^{12}$

One complication here is that the $\mathrm{CO}_{2}$ emissions factor for power generation, and embodied carbon in various (non-energy) consumer products, will fall somewhat in response to carbon pricing, as firms adopt energy-saving technologies, power generators switch to cleaner fuels, etc., though (for similar reasoning as noted above) it may be reasonable to ignore this dampening effect on consumer prices for the scale of carbon taxes considered here.

\footnotetext{
${ }^{11}$ See, for example, the spreadsheet tool at www.imf.org/external/np/fad/environ/data/data.xlsx (based on data from the International Institute for Applied Systems Analysis).

${ }^{12}$ Input output tables are available for 40 countries at www.wiod.org/new_site/database/wiots.htm.
} 


\section{Incidence Relative to Income or Expenditure?}

The appropriate definition of income against which (carbon) tax burdens should be measured for different household groups is somewhat unsettled. Annual income is problematic as many people with low annual income (students, retirees with high accumulated savings, people temporarily laid off or on maternity leave, etc.) are not poor in a lifecycle context, yet they contribute greatly to disparities in annual income across households. ${ }^{13}$ This problem is partly (though not fully, due to constraints on consumption smoothing across the lifecycle) alleviated by measuring incidence against annual consumption expenditure rather than income. Incidence studies based on expenditure suggest the potentially regressive impacts of energy or carbon taxes are much less pronounced (e.g., Poterba 1991, Hassett et al. 2009). ${ }^{14}$

\section{Household Expenditures}

Spending by household income groups on energy and non-energy products is often available from household expenditure surveys. Many advanced countries routinely conduct these surveys, ${ }^{15}$ the World Bank's Living Standards Measurement Study (LSMS) compiles them for approximately 40 developing countries, while various other developing countries (e.g., Bangladesh, Cambodia, India) administer surveys themselves. There are some concerns about the accuracy of the surveys (collecting data from thousands of households is difficult and costly) including the ability of households to remember or accurately record their expenditures, the design of the survey instrument, and data collection or entry (see Xu et al. 2007).

\section{Some Further Considerations}

This sub-section discusses the possible pass back of carbon taxes in lower supply prices and the incidence implications of co-benefits from carbon pricing.

\section{Passback of Carbon Taxes in Lower Supply Prices}

Some (albeit minor) fraction of the burden of carbon taxes may be passed backwards in lower producer prices, to the extent that fuel supply curves are upward sloping over the medium to longer term (e.g., due to scarce inputs or long-lived, sector-specific capital). To the extent this reduces the net of tax return to capital, some of the carbon tax burden is borne by owners of capital (in lower equity values or dividends) with progressive effects because the better off earn a relatively high share of their income from capital (e.g., Metcalf et al. 2008). But if (as seems plausible, even for large economies like the United States) net of tax returns to capital are largely determined in world markets, the burden of lower supply prices

\footnotetext{
${ }^{13}$ Up to one-half of the inequalities in annual income across households might be attributed to variations in income over their lifecycle rather than differences between lifecycle income (e.g., Lillard 1977).

${ }^{14}$ Regressive impacts would be milder still if a measure of lifetime income were used instead of expenditure (e.g., Walls and Hansen 1999).
} 
will tend to be borne by labor in the form of lower wages. The incidence implications here, which depend on whether pollution-intensive industries disproportionately employ low- or high-wage workers, substitution elasticities between labor, capital, and polluting inputs and so on, become difficult to estimate (e.g., Fullerton and Heutal 2011). On balance, studies for the United States suggest that the passback of carbon taxes reduces the regressivity of carbon taxes (e.g., Rausch et al. 2011), though the empirical effects are very model specific.

\section{Co-Benefits}

Carbon pricing can produce significant environmental co-benefits, for example, reduced air pollution from coal combustion and externalities like congestion from motor vehicles, at least until these other externalities are fully priced through other policies. Cobenefit estimates can be quite large, averaging $\$ 57.5$ per ton of $\mathrm{CO}_{2}$ across the top-twenty emitters (Parry et al. 2014b), though with substantial cross-country variation (e.g., due to sharp differences in population exposure to pollution).

Suppose (not unreasonably) that peoples' valuation of air pollution and other externality benefits is roughly proportional to income (OECD 2012). Then the distribution of local air pollution co-benefits across income groups within a country may be progressive if exposure risks decline with income (due to the wealthy residing in areas with cleaner air). Vehicle externality benefits (largely borne by motorists as a group) are also progressive (though to a lesser extent) given miles driven generally rises by less than in proportion to income (e.g., Pickrell and Schimek 1997). These effects are not definitive however-for example, reduced air pollution might positively affect local property values, with adverse effects for low-income renters.

\section{Implications and Importance of Revenue Recycling}

Accounting for the use of carbon tax revenues is critical, as it is the overall incidence of the policy change, including accompanying adjustments to the broader tax/social safety net system, that matters, not just the component reflecting higher energy prices. This subsection discusses how revenue recycling might affect distributional incidence and underscores the potentially high opportunity costs to diverting substantial revenues to compensation schemes.

\section{Recycling and Incidence}

Extending equation (3) above, the burden to income ratio for household $i$, accounting for recycling benefits, is:

\footnotetext{
${ }^{15}$ For example, the United States carries out the Consumer Expenditure Survey annually, the United Kingdom the Living Costs and Food Survey annually, and Eurostat the Household Budget Surveys every five years for every EU member country.
} 
(4) $\frac{B_{i}}{I_{i}} \approx \sum_{j=1}^{M} \frac{\left(p_{X 1}^{j}-p_{X 0}^{j}\right)}{p_{X 0}^{j}} \frac{p_{X 0}^{j} X_{i 0}^{j}}{I_{i}}-\alpha_{i}$

where $\alpha_{i}$ is household group i's gain (approximated by the first order transfer) from broader tax/benefit adjustments, as a proportion of their income. Clearly, the regressivity of the tax could be reduced if this gain were larger as a fraction of income for low-income households than for high-income households.

Unfortunately, accurate estimates of the distributional benefits from alternative adjustments of tax/benefit schedules through carbon tax recycling are not presently available for most countries. These schedules are typically quite complex (with numerous tax brackets subject to different marginal rates, various means-tested tax credits and benefits, etc.) so micro simulation data sets (readily available, for example, for the United States and United Kingdom, but less so for other countries) are really needed to run individual household incomes (which can be quite heterogeneous) through these schedules to compute net tax liabilities, before aggregating over household samples within a broad income category.

Even these data-based, fiscal incidence studies involve inaccuracies in that they do not typically account for behavioral responses to tax/benefit changes, nor the complicated ways in which relative prices (e.g., for labor and capital) might be affected, with secondround implications for household burdens (Boadway and Keen 2000). Computable general equilibrium models can incorporate these effects, though the results are typically sensitive to structural and parameter assumptions, and these models cannot take advantage of the highly disaggregated data reflecting intricate details of fiscal/benefit systems used in data-based studies.

One further point relates to the potential compensation for low-income households through automatic indexing of transfer and other benefit programs to higher general price levels, which is considered in some incidence studies. For example, in the United States indexing of social security payments to seniors and federal income taxes to the consumer price level, and food purchase vouchers for low income households to food prices, would offset about 10 percent of the burden of a carbon tax on the bottom income quintile according to Dinan (2014). ${ }^{16}$

\section{Costs from Revenue Diversion}

The key point from literature on interactions between environmental taxes and the broader fiscal system is the critical importance of efficient revenue use-most obviously cutting other distortionary taxes on labor, capital, and consumption-for containing policy

\footnotetext{
${ }^{16}$ Only about 40 percent of US households in the bottom income quintile receive social security benefits, and 20 percent receive food purchase vouchers. Moreover, indexing of benefits would only provide full compensation for a particular household if all (rather than a fraction) of their income was from benefits, and if their budget shares for energy were representative of (rather than higher than) those of the average household (as the latter determines the formula for calculating cost of living increases in response to higher energy prices).
} 
costs and improving social welfare (e.g., Goulder et al. 1999). The point is even more valid in light of public finance literature (e.g., Feldstein 1999, Saez et al. 2012) underscoring that broader taxes significantly distort not only the level of economic activity (by reducing the returns to work effort and capital accumulation) but also its composition (by promoting informality and excessive spending on tax-preferred goods like housing and fringe benefits).

Figure 2 underscores the point with illustrative calculations of the efficiency costs of a carbon tax (excluding environmental benefits), expressed as a percent of GDP, for a representative, large-emitting economy, under plausible (though very crude) assumptions about the price-responsiveness of emissions and the efficiency costs of broader taxes. The main point here is that with revenue recycling the efficiency costs of carbon taxes reducing emissions by around 20 percent or less (i.e., $\mathrm{CO}_{2}$ taxes up to around $\$ 60$ per ton) are very small, and perhaps even slightly negative, ${ }^{17}$ while deadweight costs are substantial— 0.75 percent of GDP for a 20 percent emissions reduction-when carbon tax revenues are returned lump sum, or in other ways that do not increase economic efficiency.

A key implication is the potentially high opportunity costs to diverting revenues from the general budget to compensation schemes that do not enhance economic efficiency. Avoiding unnecessary compensation is therefore important and, where possible, using compensation measures promoting economic efficiency (e.g., targeted reductions in personal income and payroll taxes and earned income tax credits all of which increase returns from formal work effort.

\section{E. Summary}

A first-pass assessment of carbon tax incidence in many different countries, prior to revenue recycling, can be obtained based on $\mathrm{CO}_{2}$ emissions factors, energy prices, input output tables (to measure indirect consumer price effects) and expenditure patterns for household income groups. Although there are complicating factors (e.g., behavioral responses, changes in producer prices, co-benefits from carbon pricing) it is difficult to make general statements about how they affect overall incidence (even directionally). Broader adjustments to the tax/benefit system that accompany carbon taxes need to be integrated into incidence analyses, while making transparent that revenue diversion from the general budget for compensation involves significant costs, for example by reducing opportunities for cutting other taxes that distort economic activity.

\footnotetext{
${ }^{17}$ The negative cost result differs from the standard implication of Diamond and Mirrlees (1971), that swapping product taxes for broader income taxes will (under neutral assumptions) increase efficiency costs. The reason is that Diamond and Mirrlees do not incorporate distortions from the broader fiscal system, beyond those in factor markets. See Parry and Bento (2000) for more explanation.
} 


\section{Incidence ACross Advanced Countries: A Broad Picture}

The subsections here pull together various data sources to paint a very broad picture of overall carbon tax incidence for advanced countries, before and after revenue recycling. Box 2 provides some brief remarks for developing countries.

\section{A. Incidence Prior to Recycling}

We start with the first-order, economy-wide burden of a $\mathrm{CO}_{2}$ tax using an illustrative tax rate of $\$ 35$ per ton ${ }^{18}$, the impacts of the tax on various (energy and other) product prices, and then match this to data on household budget shares.

\section{Economy-wide Incidence}

Figure 3 shows, for selected advanced countries in 2012 (and ignoring behavioral responses), the first-order burden of the $\$ 35 \mathrm{CO}_{2}$ tax-the tax revenue as a percent of GDP, decomposing the tax that would be paid by primary fuels. ${ }^{19}$

The tax burdens vary from below 0.5 percent of GDP in Denmark, France, Norway, Sweden and Switzerland-countries where there is relatively little use of coal in particular, but also natural gas - to over 1.5 percent in the Czech Republic, Korea and Poland-which are all relatively heavy coal users.

\section{Price Impacts}

Figure 4 provides some flavor of the direct impacts of a $\$ 35$ per ton $\mathrm{CO}_{2}$ tax on household energy prices in advanced countries. Specifically, it shows (assuming full pass through and calculated as discussed above) the percentage increase in energy prices for 2012 (or thereabouts) for residential electricity, natural gas, gasoline, and diesel.

The absolute price increases for natural gas, gasoline, and diesel, are essentially uniform for each fuel across countries (given uniform emissions factors), though proportionate price increases are larger in countries with relatively low energy prices. For example, household gas prices increase by around 20 percent in Canada, Mexico, and the United States (where supply costs and taxes are low), but less than 6 percent in Chile, Denmark, Greece, Japan, and Sweden (where supply costs are higher and, for Denmark and Sweden, specific taxes are levied in addition to value-added tax). Similarly, gasoline and diesel prices increase by more than 8 percent in Mexico and the United States (where fuel taxes are relatively low), while these prices rise by less than 5 percent in most other cases

\footnotetext{
${ }^{18}$ This figure is based on the central case of US IAWG (2013). If applied to leading $\mathrm{CO}_{2}$ emitting countries, this starting price would be broadly consistent with keeping long-run, mean projected warming to around $2.5^{\circ} \mathrm{C}$ (Nordhaus 2013, pp. 228).

${ }^{19}$ The $\mathrm{CO}_{2}$ tax is superimposed on top of any existing $\mathrm{CO}_{2}$ pricing (e.g., around $\$ 10$ per ton for covered emissions in the EU trading system).
} 
(the percent increase in diesel prices is a bit larger than for gasoline due to the higher emission factor and in many cases lower tax rate for diesel).

For electricity, there is substantial variation in the absolute price increase, from over US 2.5 cents per kilowatt hour (kWh) in Estonia, Greece, and Israel (where power generation is fossil fuel intensive) to about 0.25 cents per kWh or less in France, Norway, Sweden, and Switzerland (where there is little reliance on fossil generation). Percent price increases exceed about 15 percent in Estonia, Israel, Mexico, Korea, and the United States, while they are less than 2 percent in France, Norway, Sweden, and Switzerland.

As regards the indirect impacts of carbon taxes on the prices of other consumer products, for the United States, Morris and Mathur (2015) estimates these price effects for a $\$ 15$ per ton $\mathrm{CO}_{2}$ tax in 2010. The prices of other products rise, but in most cases by a fairly modest percentage compared with energy price increases. For example, some consumer prices (e.g. clothing, health) rise by less than 0.5 percent, and others (e.g., mass transit, household supplies) by between 0.5 and 1 percent, though in some cases (e.g., auto purchases and parts, air and transit travel) price rises are somewhat more significant at between 1 and 2 percent.

Figure 5 shows the contribution of direct and indirect price effects to the burden of a carbon tax, expressed relative to income and consumption, as borne by different income quintiles in the United States. Burdens from indirect price effects are smaller than those from the direct price effects and smaller in relative terms for lower-income groups (the size of the indirect burden relative to the direct burden falls from 54 percent for the top income quintile to 42 percent for the bottom income quintile for the consumption-based measure). Therefore, accounting for indirect effects moderately increases progressivity.

Speaking very loosely, for other advanced countries we might expect the increases in (non-energy) consumer products to either follow a broadly similar pattern to those in Morris and Mathur (2015) in countries like Estonia, Mexico, and Korea (where proportionate increases in electricity prices are broadly similar to those for the United States) or to rise more moderately in the majority of cases (where proportionate increases in electricity prices are less pronounced than in the United States). In the latter cases this implies an even smaller burden from indirect price effects, relative to the burden from direct price effects.

\section{Cross-Country Incidence}

A consistent, cross country database of carbon tax incidence is not available from previous studies, as these studies either have an individual country focus or look at the incidence of energy taxes (see Box 1). Here we crudely extrapolate carbon tax incidence for advanced countries as follows.

We start with data, by income quintile, on the share of consumption paid in electricity, heating, and motor fuels taxes, reported in OECD (2014). Next we divide by tax rates (from IEA 2014) and multiply by the absolute energy price increases underlying Figure 4 (proxying heating by natural gas) to give the burden by quintile of the direct impacts on 
energy prices of a $\$ 35$ per ton $\mathrm{CO}_{2}$ tax. Finally, burdens from indirect price increases are inferred using, by quintile, the ratio of burdens from indirect and direct price increases from Figure 5 (for consumption), after scaling these ratios by the proportionate increase in electricity prices in other countries relative to those in the United States. ${ }^{20}$

The result, for selected countries, is shown in Figure 6. Cross-country differences reflect differences in carbon-tax-induced energy price impacts (relatively high for Estonia and United Kingdom and low for Belgium and France-see Figure 4) and initial budget shares for energy. But the main point here is that, within countries, effects vary from moderately regressive (e.g., Austria, Czech Republic, Estonia, Poland, United Kingdom) to roughly proportional (Belgium, Finland, Germany), to moderately progressive (Slovenia, Turkey).

\section{B. Incidence after Recycling}

This section considers distributional impacts from the use of carbon tax revenues, first if used for reductions in other energy excises (on electricity and vehicles) and then for adjustments to the broader tax and benefit system.

\section{Reducing other Energy Taxes}

One possibility for offsetting, in a transparent way, some of the carbon-tax-induced burden on households from higher energy prices might be to lower pre-existing taxes on energy that the carbon tax makes redundant on climate grounds. The main targets here are excises on residential electricity consumption, and on vehicle sales, that are applied across many advanced countries. ${ }^{21}$

Figure 7 shows, for a selection of advanced countries, what portion of the increase in residential electricity prices, and motor fuel prices (weighting across gasoline and diesel fuel prices) induced by a $\$ 35$ per ton $\mathrm{CO}_{2}$ tax could be offset by lowering pre-existing excises, where they apply. For 11 out of 23 countries, the burden on households from higher electricity prices could be completely neutralized through offsetting reductions in electricity excises, or put another way, current excises exceed (often by well over 100 percent) the impact of carbon taxes on residential electricity prices. ${ }^{22}$ And in 18 cases, the burden of higher motor fuel prices could be neutralized, on an annualized basis, by lowering excises on motor vehicle sales.

\footnotetext{
20 This latter adjustment does not substantially alter overall incidence patterns, given that the indirect burdens are minor relative to direct burdens.

21 These taxes are imposed in addition to taxes (value added or similar general sales taxes) on consumer goods in general.

${ }^{22}$ For many EU countries, cutting electricity excises would not conflict with the EU Energy Tax Directive, given that it imposes a relatively modest floor tax on electricity equivalent to about US 0.07 cents per kWh.
} 
There is little scope however, in many countries, for offsetting the burden of higher natural gas prices on households, or the indirect impacts on the prices of other consumer products, through cutting pre-existing excises. And of course, scaling back electricity and vehicle excises will (moderately) offset some of the emissions reductions from carbon taxes and reduce, quite substantially, the net revenues from the carbon tax-potentially in proportion to the share of (residential) electricity and motor fuels in total $\mathrm{CO}_{2}$ emissions. ${ }^{23}$

\section{Adjusting the Broader Tax/Benefit System}

The distributional impacts of potential adjustments to the broader tax/benefit system accompanying a carbon tax will depend on country specifics-like the underlying distribution of pre-tax income and rates/brackets in personal income tax schedules-therefore the discussion here offers only some general remarks, along with some statistics for the United States.

Figure 8 shows the share of income from various federal taxes, and a prospective carbon tax, in the United States by income quintile. Payroll taxes are approximately proportional up to the top income quintile, where they become regressive (due to the cut-off beyond which the marginal tax rate drops to zero). In contrast the personal income tax is quite progressive, due to tax credits at the bottom end (making the average tax burden negative), tax allowances, and rising marginal rates. Less important in terms of tax burdens are excises which are regressive and corporate income taxes which are progressive at the upper end (though accurately measuring the incidence of this tax is difficult-see below).

As regards personal income taxes, a proportional reduction in marginal tax rates will perform well on efficiency grounds (improving incentives for work effort, savings, and reducing incentives for tax sheltering) but will have regressive effects. On the other hand, raising personal income tax thresholds disproportionately benefits (relative to their income) low-income households, though the tax reduction (the increase in the threshold times the household's marginal tax rate) is larger in absolute terms for higher income households. Extending tax credits (e.g., for child care) is a bit better in this regard, as the value of the credit is the same for all taxpayers. Better still (in terms of targeting low-income households) is expanding earned income tax credits, which phase out as income rises. None of these measures reach all low-income households however, some of whom do not pay income tax. Moreover, the economic efficiency gains from these tax reductions are smaller than for cuts in marginal tax rates - they promote labor force participation and shifting from informal to formal work effort (which depend on average tax rates) but not hours worked on the job or shifting from tax-preferred to ordinary spending (which depend on marginal tax rates). Efficiency gains from cutting payroll rates are likely somewhat smaller than those for cutting income tax rates, as there are fewer exemptions and deductions for payroll taxes (e.g., fringe benefits are exempt but mortgage interest is not).

\footnotetext{
${ }^{23}$ The burden of higher energy prices might also be offset by introducing 'subsistence' thresholds for energy consumption below which no tax is paid. Although this measure is progressive, it is similar to using revenues for lump-sum transfers (see the discussion below), which yields no efficiency gains.
} 
The burden of corporate income taxes largely falls on labor in countries with globally integrated capital markets (where the net of tax return to capital cannot be pushed down below that available in other countries). Although the burden across workers at different earnings levels is unclear, capital and skills may be complementary so that cutting corporate income taxes disproportionately benefits high-wage workers. Cutting capital taxes likely produces the biggest source of efficiency gains, given the international mobility of the tax base, though in large part at the expense of welfare losses in other countries suffering the capital flight-indeed tax theory (Kanbur and Keen 1993) suggests that other countries will respond by cutting their own capital taxes, thereby dampening efficiency gains in the domestic economy.

Compared with tax systems, benefit programs potentially offer a far more efficient means to redistribute to lower-income households. The drawback of most benefit programs (e.g., social security, unemployment, housing, family-dependent benefits) is that they do not increase economic efficiency. Nonetheless, at least for the United States, only a minor fraction of the 10 percent or so of carbon tax revenues needed to keep the bottom income quintile whole (40 percent, or 4 percent of carbon tax revenue, according to Dinan 2015) need come from these types of instruments.

Finally, in addition to recycling carbon tax revenues in tax cuts/benefit increases, numerous other accompanying fiscal adjustments could alter the incidence of a fiscal package containing a carbon tax, most obviously scaling back tax expenditures disproportionately benefitting the better off. Cutting, for example, reliefs for pension contributions, estates transferred at death, state and local income taxes, mortgage interest, charities, capital gains and dividends, could all have progressive effects (e.g., CBO 2013).

\section{Summary}

The general theme of the above discussion is that distributional concerns are potentially manageable. For one thing, the energy price impacts of carbon taxes may not be that regressive, at least if incidence is measured against household consumption, and may be proportional, or even progressive in some countries. For another, there are numerous opportunities in advanced countries for compensating low-income households through recycling carbon tax revenues in targeted tax cuts/benefit increases and for combining carbon taxes with other progressive measures, though the specifics need to be carefully examined on a country-by-country basis. Failing to charge for carbon damages is in fact a very inefficient distributional policy as the vast majority of benefits leak away to higher income groups, or put another way, only a small fraction of the carbon tax revenues are needed to compensate low-income households. Even for this group, a large portion of the compensation could take the form of tax cuts and earned income tax credits (that have some efficiency benefits) rather than transfer payments (that do not). As regards the recycling of other revenues, policymakers typically need to trade off efficiency and distributional objectives (tax reductions with higher efficiency gains tend to be more regressive) though there is always scope for other adjustments (e.g., reforming tax preferences) to promote distribution neutrality in a broad fiscal package. 


\section{Conclusion}

The general message of this paper is that, while distributional concerns are potentially important both for fairness and the politics of reform, they should not hold up establishing a robust price on $\mathrm{CO}_{2}$ emissions.

We conclude by noting a couple of carbon pricing schemes that seem needlessly costly. One is emissions trading systems where allowances are given away for free to existing emitters. Not only does this policy forego large economic efficiency gains from recycling revenues in other tax reductions, it does nothing to improve distributional outcomes across households - in fact it may greatly worsen them by transferring windfall profits to wealthy households via higher equity values for firms receiving free allowances (Dinan and Rogers 2002, Parry 2004). The other scheme, 'tax and dividend', also forgoes large efficiency benefits, by returning 100 percent of carbon tax revenues to households in equal lump-sum transfers. As emphasized above (for the United States), only around 10 percent of revenues are needed to compensate bottom income quintiles, and only a minor portion of this need take the form of instruments (like transfer payments) that do not increase economic efficiency. 


\section{Box 1. Some Prior Literature}

There have been several country case studies of carbon and energy tax incidence (mostly prior to revenue recycling), and some recent cross-country comparisons of energy tax incidence but not much crosscountry assessment of carbon tax incidence. This box provides a quick flavor of some of this literature.

Most work on energy tax incidence focuses on motor fuels, a recent example being Sterner (2012). He finds these taxes are generally more regressive in the United States than Europe (primarily due to higher vehicle ownership rates among lower income households in the former). And when incidence is measured using consumption expenditure (arguably a better measure- see text) rather than annual income, motor fuel taxes are often progressive, at least across low- to middle-income groups. Poterba (1991) found similar results for the United States: the burden to income ratio for the bottom income quintile is 5.3 times that for the top income quintile with incidence based on annual income, but only 1.5 times that for the top income quintile with incidence based on expenditure.

Casler and Rafiqui (1993) looked at a range of taxes on electricity, coal, natural gas, gasoline, and other refined petroleum products for the United States, finding that the tax burden to income ratio overall for the lowest income quintile is only modestly larger than for the top income quintile (in part because indirect price effects are less regressive than the direct price effects). In a similar study, Bull et al. (1994) show that incidence effects of energy taxes are even less regressive with incidence based on consumption. Metcalf (1999) demonstrates that similar energy tax packages can be made distributionally neutral overall for broad income groups (under income and consumption incidence measures) through targeted income and payroll tax reductions.

As regards country-specific analyses of carbon pricing, US applications include Dinan (2015), Hassett et al. (2009), Morris and Mathur (2015), Parry and Williams (2010), Rausch et al. (2011), with most focusing on neutralizing adverse distributional effects through revenue recycling. Prior to recycling, the burden to income ratio for low-income households is roughly 3-5 times that for high-income households, or about 1.5 times as high, based on income and consumption incidence measures respectively. The two big direct items are motor fuels and electricity, with the budget share for electricity falling most rapidly with higher income. Similar analyses for other countries include Australia (e.g., Cornwell and Creedy 1997), Denmark (e.g., Wier et al. 2005) and Sweden (e.g., Brännlund and Nordström 2004).

As regards cross-country assessments, an early study by Smith (1992), covering a variety of countries and focusing on income-based incidence, finds that carbon and energy taxes are moderately regressive for most countries, but more so for the United Kingdom and Ireland (where, due to colder climates, heating/electricity needs are greater). A recent study of European countries (measuring incidence against expenditure) by OECD (2014) finds that transportation taxes are generally progressive, heating fuel taxes are regressive, but only slightly so, while electricity taxes are more regressive. 


\section{Box 2. Carbon Tax Incidence in Developing Countries}

This Box makes three broad points about carbon tax incidence in developing countries.

First, carbon taxes might be less regressive in developing countries than in advanced countries if access to the power grid and vehicle ownership is skewed towards higher income groups (though low income households are affected by diesel fuel taxes indirectly through higher bus fares). Some suggestive evidence to back up this possibility comes from incidence studies of petroleum product subsidies, which are largely concentrated in the Middle East and North Africa. According to Clements et al. (2013), Figure 3.12, on average the bottom income quintile receives only 3 percent of the benefits from gasoline subsidies, 7 percent from diesel fuel subsidies, and 4 percent from liquefied petroleum gas subsidies.

Second, the case for including carbon taxes as part of the fiscal system could be stronger in developing countries than advanced countries, if large informal sectors constrain the revenue bases of broader fiscal instruments like personal income taxes and value added tax. Carbon, and more general energy, taxes can help broaden the tax base into the informal sector (e.g., Bento et al. 2012).

Third however, targeted compensation for low-income households can be more challenging, at least if many people are not formally registered as taxpayers or benefit recipients. Besides strengthening social safety nets, use of carbon tax revenues for broader spending on health, education, housing, job programs, clean fuel alternatives, and so on, may be needed to maintain equity objectives in light of higher energy prices, though this likely involves greater leakage of program benefits to the non-poor. 


\section{Figure 1. Burden of a Fuel Tax for a Household Group}

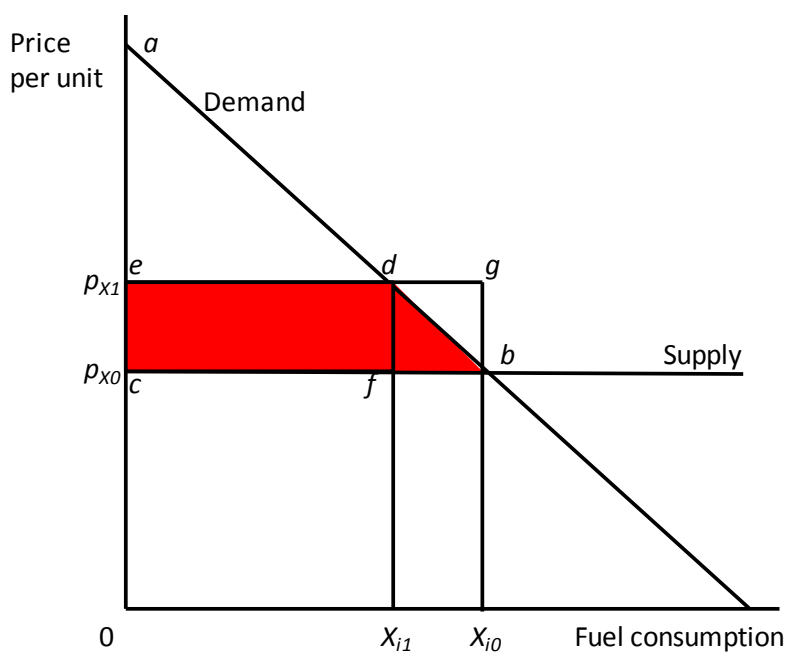

Note. The red trapezoid indicates the burden (loss of consumer surplus) to a household group from the increase in price (caused by a carbon tax) for a particular fuel.

\section{Figure 2. Illustrative Cost of a Carbon Tax, with and without Revenue Recycling}

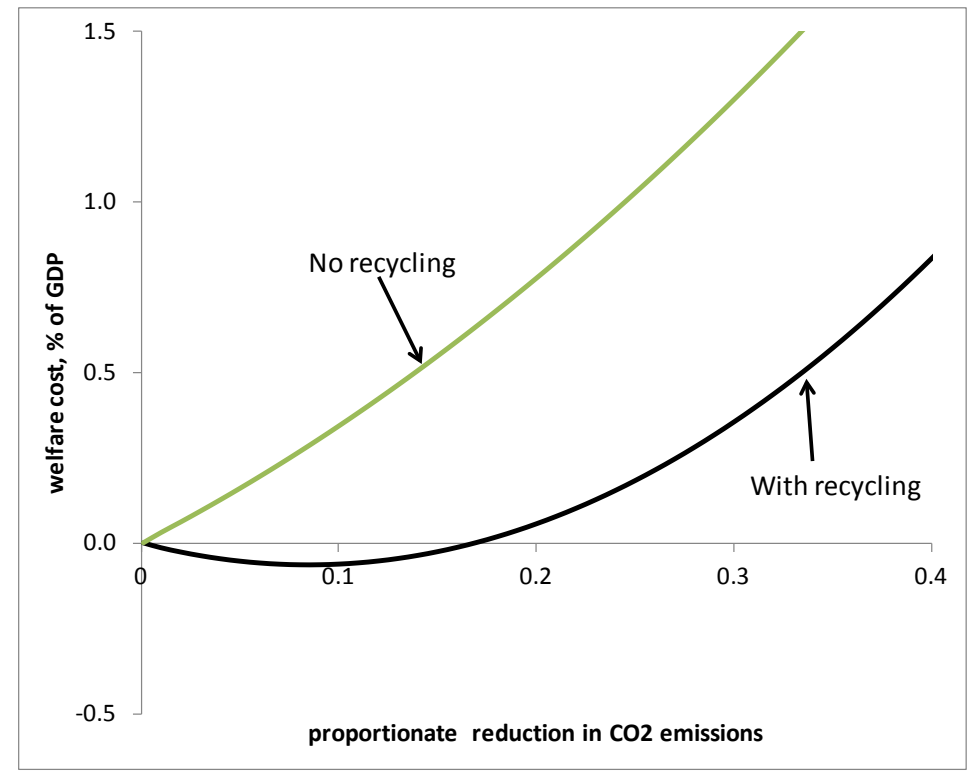

Source. Based on formulas in Parry and Williams (2010), assuming: a $\mathrm{CO}_{2}$ intensity of 0.5 tons per $\$ 1000$ of GDP (about average for the top twenty $\mathrm{CO}_{2}$ emitting countries - see Parry, Veung, and Heine 2014); each successive \$3 per ton increase in the $\mathrm{CO}_{2}$ tax reduces emissions by 1 percent; and a marginal efficiency cost of $\$ 0.3$ per extra dollar of revenue raised from broader taxes, with 60 percent and 40 percent of this due to distortions in the level of, and composition of, economic activity respectively.

Note. Costs with recycling are (moderately) negative over some range, which differs from the general tax results derived in Diamond and Mirlees (1971), due to the inclusion here of additional distortions (affecting the composition of economic activity) from the broader fiscal system, beyond those in factor markets (affecting only the level of economic activity). 
Figure 3. First-Order Burden from a $\$ 35$ per ton $\mathrm{CO}_{2}$ Tax, Selected Countries, 2012

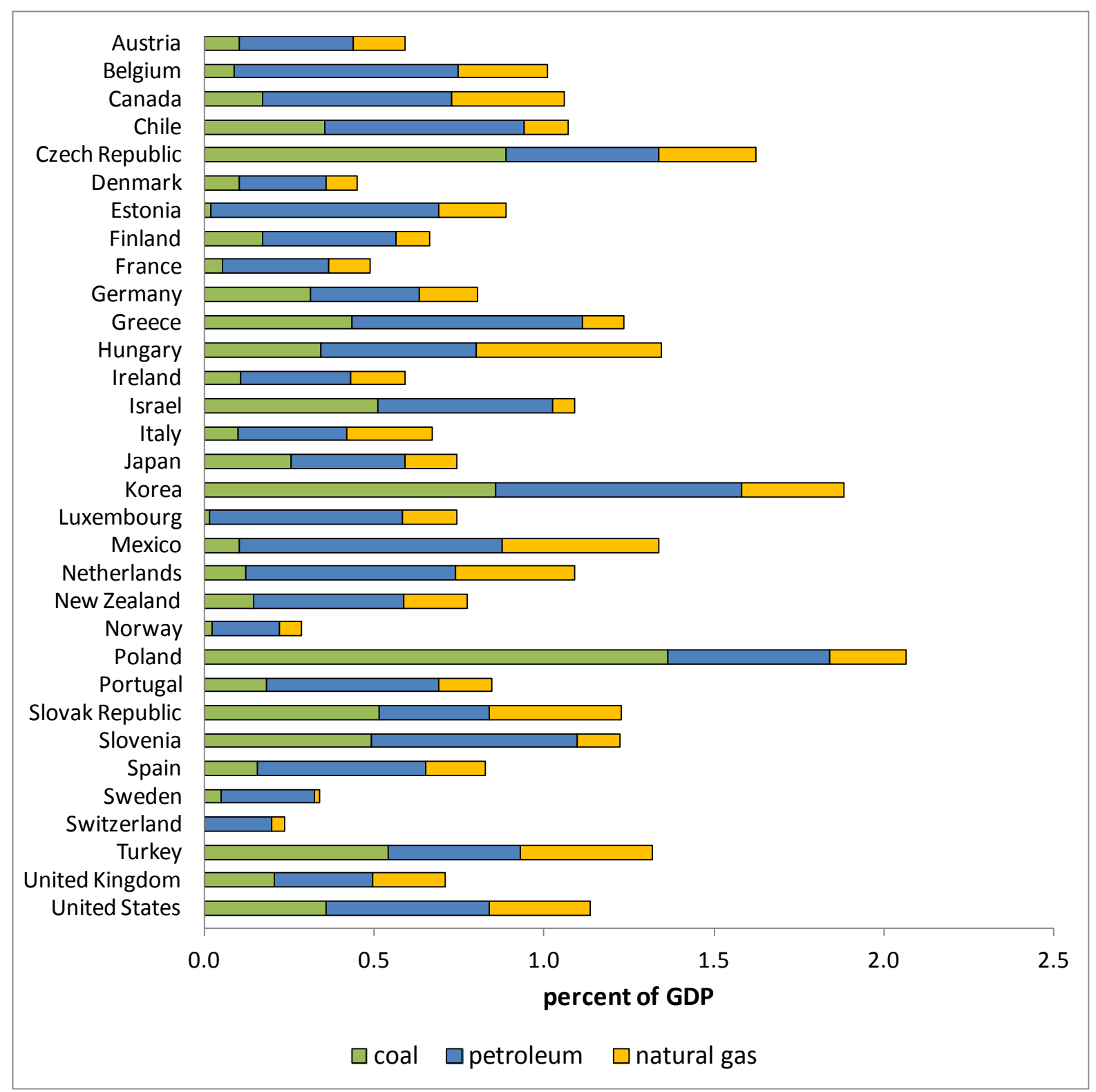

Source. IEA (2014), IMF (2015).

Notes. Figure shows the first order burden of a $\mathrm{CO}_{2}$ tax (excluding behavioral responses), that is, the tax rate times current emissions, expressed as a percent of GDP, and decomposed according to the contribution of different primary fuels to $\mathrm{CO}_{2}$ emissions. 
Figure 4. Increase in Energy Prices for a $\$ 35$ per ton $\mathrm{CO}_{2}$ Tax, Selected Countries, 2012

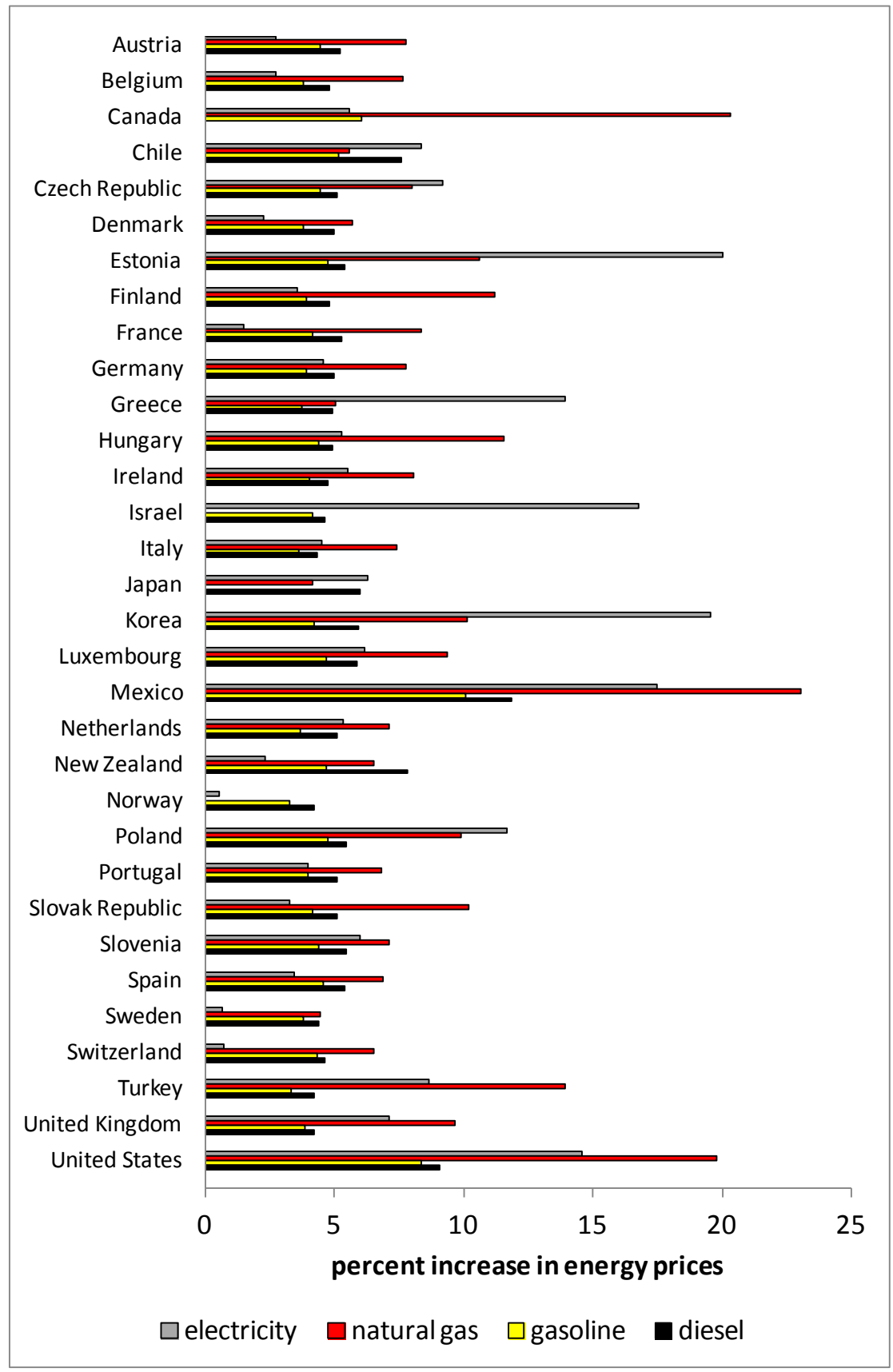

Sources. IEA (2014), Parry et al. (2014).

Notes. All data is for year 2012, aside from the $\mathrm{CO}_{2}$ emissions factors (from IEA) which were available for 2011. Price increases are calculated by the $\mathrm{CO}_{2}$ emissions factor for each fuel, times $\$ 35$ per ton, divided by the baseline household price. 
Figure 5. Direct and Indirect Burden of a Carbon Tax by Income Quintile in the United States, 2010

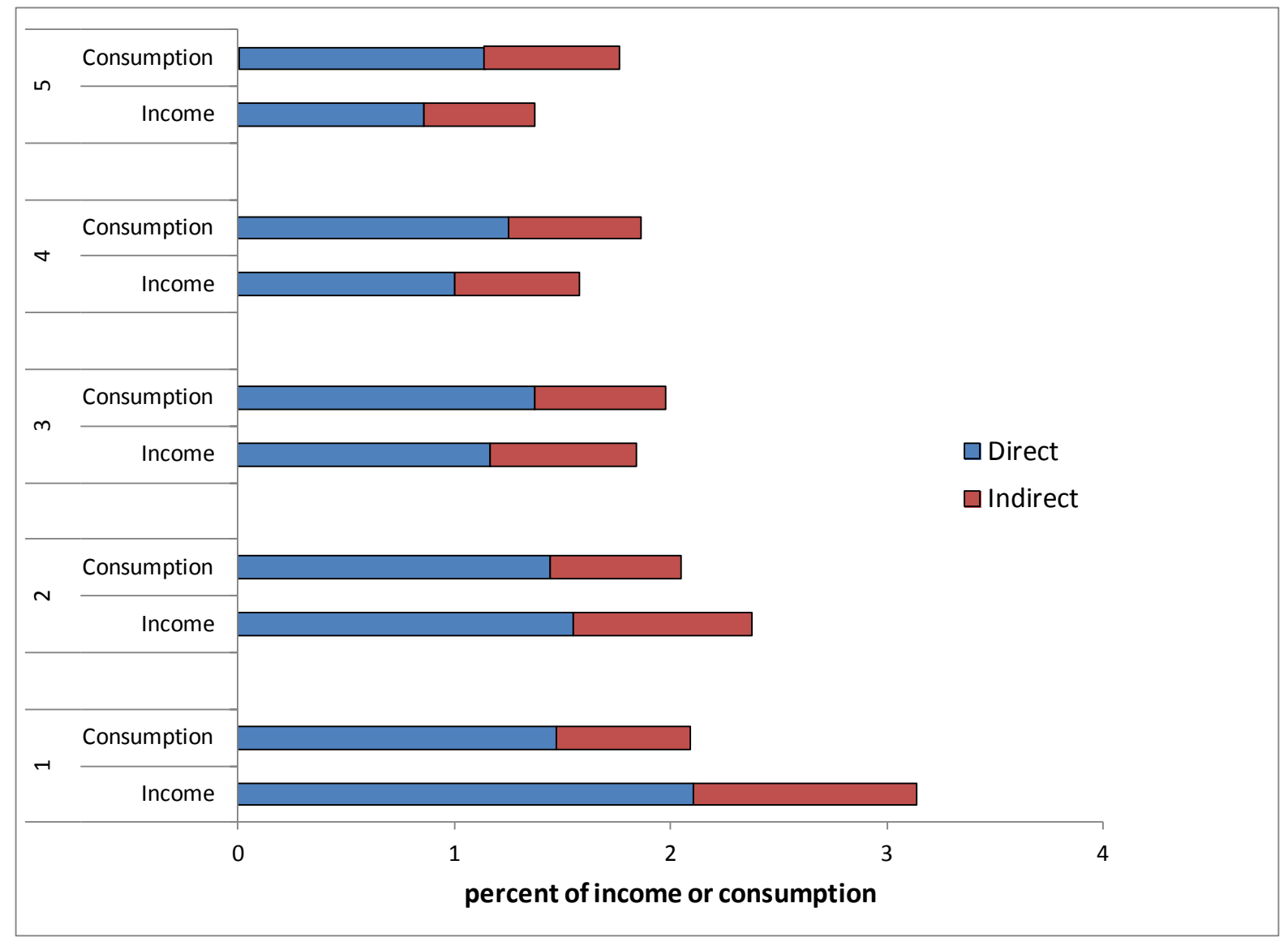

Source. Morris and Mathur (2015).

Notes. Calculations are a simple average over data for income deciles. 
Figure 6. Carbon Tax Incidence by Income Quintiles Prior to Revenue Recycling, Selected Countries, 2012

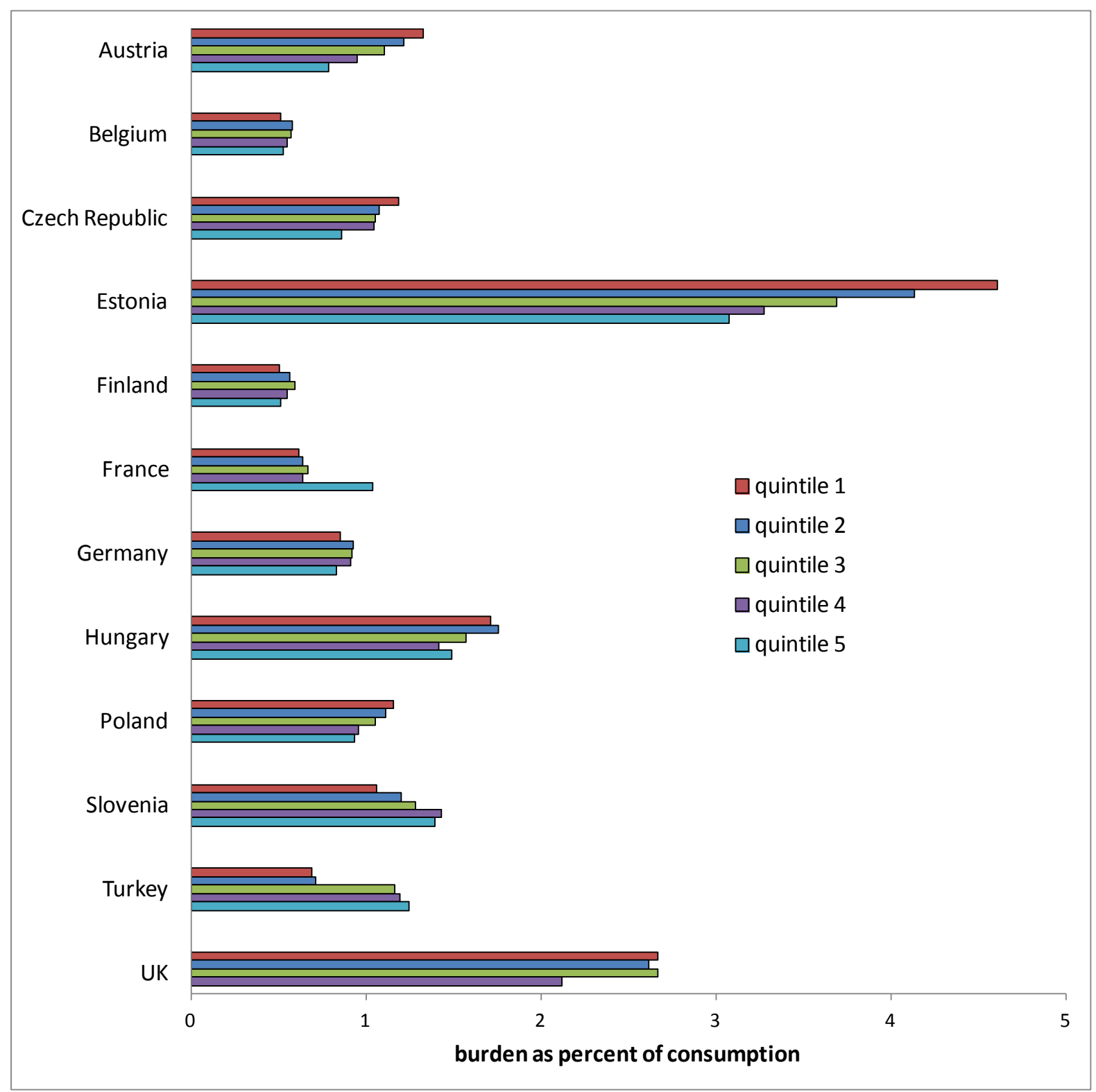

Sources. Author's calculations using OECD (2014) and IEA (2014). 


\section{Figure 7. Burden of Higher Household Energy Prices that could be Offset by Lowering Other Energy Taxes, Advanced Countries, 2010}

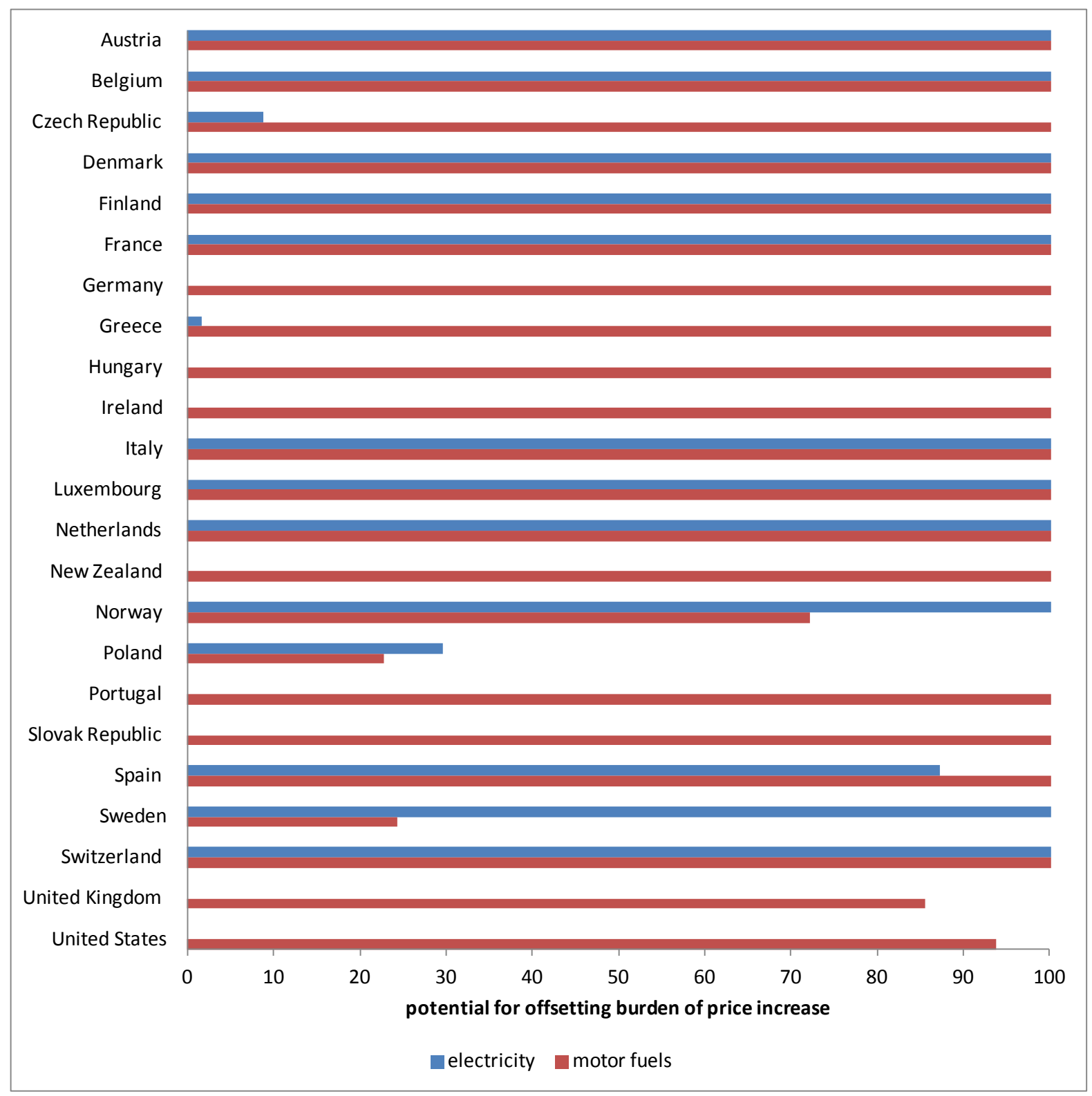

Sources. IEA (2014), IMF (2011).

Notes. For electricity, the bar shows the percentage of the increase in residential electricity prices from a $\$ 35$ per ton $\mathrm{CO}_{2}$ tax that could be offset by lowering a pre-existing excise tax on residential electricity consumption. For motor fuels, a bar shows the percentage of the increase in motor fuel prices from the same carbon tax that could be offset (on an annualized basis) by lowering excises on vehicle sales. 
Figure 8. Share of Federal Taxes by Income Quintile, United States, 2009

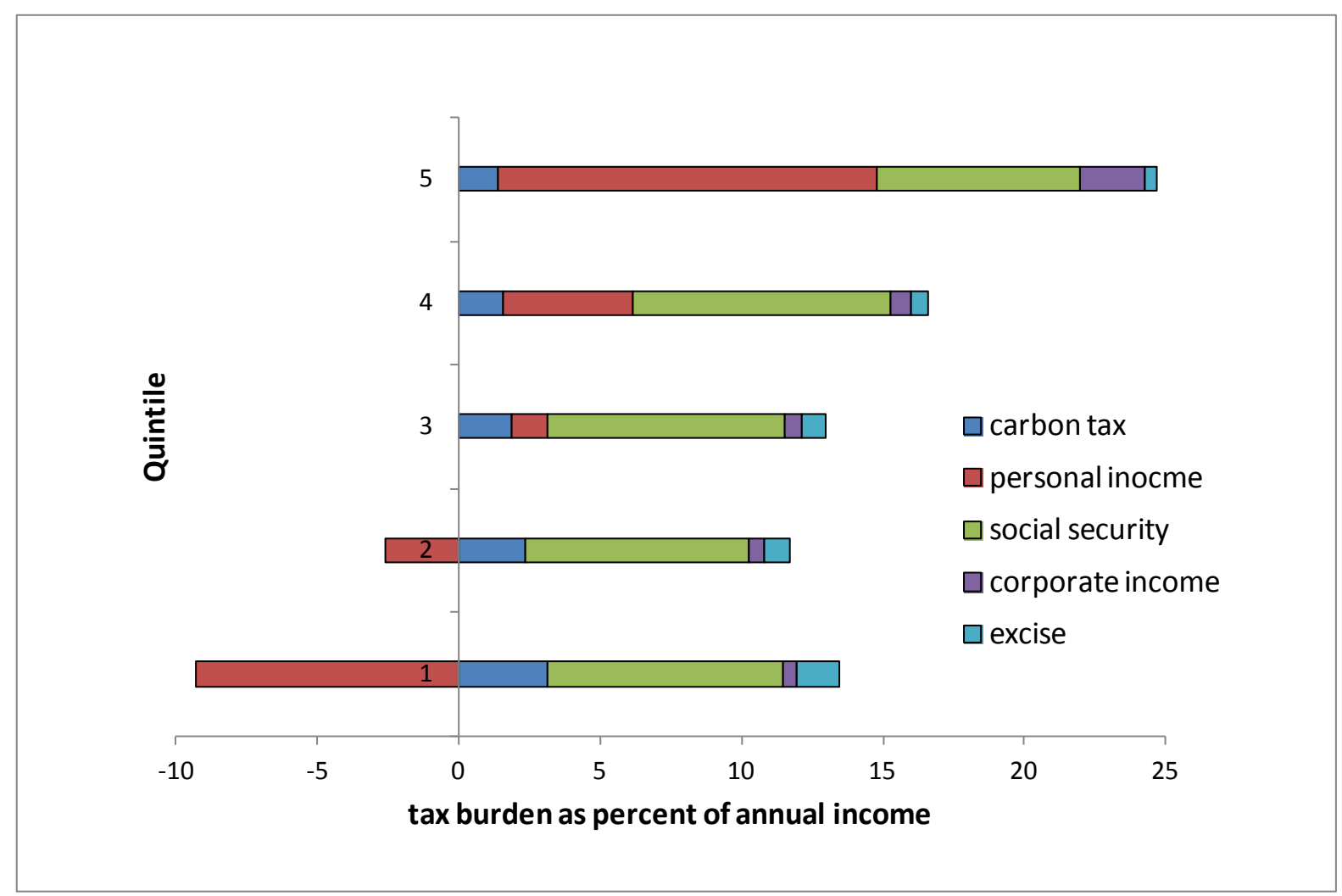

Sources. CBO (2012) and Figure 6 above.

Notes. Carbon tax burden is for 2010. 


\section{REFERENCES}

Bento, Antonio, Mark Jacobsen, and Antung A. Liu, 2012. "Environmental Policy in the Presence of an Informal Sector.” Discussion paper, Cornell University.

Boadway, Robin and Michael Keen, 2000. "Redistribution." In A. Atkinson and F. Bourguignon (eds.), Handbook of Income Distribution, Elsevier, New York.

Böhringer, C., J.C. Carbone and T.F. Rutherford. 2012. "Unilateral Climate Policy Design: Efficiency and Equity Implications of Alternative Instruments to Reduce Carbon Leakage.” Energy Economics 34 (Supplement 2): S208-S217 (December).

Brännlund, Runar and Jonas Nordström, 2004. "Carbon Tax Simulations Using a Household Demand Model.” European Economic Review 48: 211-33.

Bull, Nicholas, Kevin Hassett, and Gilbert Metcalf, 1994. "Who Pays Broad-Based Energy Taxes? Computing Lifetime and Regional Incidence.” The Energy Journal 15: 145-64.

Calder, Jack, 2015. “Administration of a US Carbon Tax.” In I. Parry, A. Morris and R. Williams (eds.), Implementing a US Carbon Tax: Challenges and Debates, Routledge: 3861.

Casler, Stephen D. and Aisha Rafiqui, 1993. "Evaluating Fuel Tax Equity: Direct and Indirect Distributional Effects.” National Tax Journal 46: 197-205.

CBO, 2012. The Distribution of Household Income and Federal Taxes, 2008 and 2009. Congressional Budget Office, Washington DC.

CBO, 2013. The Distribution of Major Tax Expenditures in the Individual Income Tax System. Congressional Budget Office, Washington DC.

Clements, Benedict, David Coady, Stefania Fabrizio, Sanjeev Gupta, Trevor Alleyene, and Carlo Sdralevich (eds.), 2013. Energy Subsidy Reform: Lessons and Implications. International Monetary Fund, Washington, DC.

Cornwell, Antonia and John Creedy, 1997. "Measuring the Welfare Effects of Tax Changes Using the LES: An Application to a Carbon Tax.” Empirical Economics 22: 589-613.

Diamond, Peter A. and James A. Mirrlees, 1974. "Optimal taxation and Public Production I: Production Efficiency and II: Tax Rules.” American Economic Review 61: 8-27, and 261278.

Dinan, Terry, 2015. “Offsetting a Carbon Tax’s Burden on Low-Income Households.” In I. Parry, A. Morris and R. Williams (eds.), Implementing a US Carbon Tax: Challenges and Debates. Routledge, forthcoming, 38-61. 
Dinan, Terry M. and Diane Lim Rogers, 2002. "Distributional Effects of Carbon Allowance Trading: How Government Decisions Determine Winners and Losers.” National Tax Journal LV: 199-222.

Espey M., 1998. "Gasoline Demand Revisited: An International Meta Analysis of Elasticities.” Energy Economics 20: 273-295.

Espey, J.A. and Espey M., 2004. "Turning on the Lights: A Meta Analysis of Residential Electricity Demand Elasticities.” Journal of Agricultural and Applied Economics 36: 65-81.

Feldstein, Martin, 1999. "Tax Avoidance and the Deadweight loss of the Income Tax." Review of Economics and Statistics LXXXI: 674-680.

Fischer, Carolyn, Richard Morgenstern, and Nathan Richardson, 2015. "Carbon Taxes and Energy Intensive Trade Exposed Industries: Impacts and Options.” In I. Parry, A. Morris and R. Williams (eds.), Implementing a US Carbon Tax: Challenges and Debates, Routledge, 159-177.

Fullerton Don and Garth Heutel, 2011. “Analytical General Equilibrium Effects of Energy Policy on Output and Factor Prices.” The B.E. Journal of Economic Analysis \& Policy 10: 126.

Goulder, Lawrence H., Ian W.H. Parry, Roberton C. Williams, and Dallas Burtraw, 1999. "The Cost-Effectiveness of Alternative Instruments for Environmental Protection in a Second-Best Setting.” Journal of Public Economics 72: 329-360.

Hassett, K., A. Marthur, and G. Metcalf, 2009. “The Incidence of a US Carbon Tax: A Lifetime and Regional Analysis.” The Energy Journal 30: 155-178.

IEA, 2014. World Energy Statistics and Balances. International Energy Agency, Paris, France.

IMF, 2011. Promising Domestic Fiscal Instruments for Climate Finance. Paper prepared for the G20. International Monetary Fund, Washington, DC. Available at: www.imf.org/external/np/g20/pdf/110411b.pdf.

IMF, 2015. World Economic Outlook Database. International Monetary Fund, Washington, DC. Available at: www.imf.org/external/pubs/ft/weo/2014/02/weodata/index.aspx.

Immervoll, Herwig and Linda Richardson, 2011. Redistribution Policy and Inequality Reduction in OECD Countries: What Has Changed in Two Decades? IZA Discussion Paper 6030, Bonn, Germany.

Kanbur, Ravi, and Michael Keen, 1993. “Jeux Sans Frontiers: Tax Competition and Tax Coordination When Countries Differ in Size.” American Economic Review 83: 877-892. 
Lillard, L. A., 1977. “Inequality: Earnings versus Human Wealth.” American Economic Review 67: 42-53.

Metcalf, Gilbert E., 1999. “A Distributional Analysis of Green Tax Reforms.” National Tax Journal 52: 665-681.

Metcalf, G., J.F. Holak, H. Jacoby, S. Paltsev, and J. Reilly, 2008. "Analysis of US Greenhouse Gas Tax Proposals.” NBER Working Paper No. 13980. Cambridge, MA, National Bureau of Economic Research.

Morris, Adele, and Aparna Mathur, 2015. "The Distributional Burden of a Carbon Tax: Evidence and Implications for Policy.” In I. Parry, A. Morris and R. Williams (eds.), Implementing a US Carbon Tax: Challenges and Debates. Routledge, forthcoming, 38-61.

Nordhaus, William D., 2013. The Climate Casino: Risk, Uncertainty, and Economics for a

OECD, 2012. Mortality Risk Valuation in Environment, Health and Transport Policies. Organization for Economic Cooperation and Development, Paris.

OECD, 2014. The Distributional Incidence of Energy Taxes. Organization for Economic Cooperation and Development, Paris.

Parry, Ian W.H. and Antonio M. Bento, 2000. “Tax Deductions, Environmental Policy, and the "Double Dividend" Hypothesis." (With). Journal of Environmental Economics and Management 39: 67-96.

Parry, Ian W.H., 2004. “Are Emissions Permits Regressive?” Journal of Environmental Economics and Management 47: 364-387.

Parry, Ian W.H. and Roberton Williams, 2010. "What are the Costs of Meeting Distributional Objectives for Climate Policy?” B.E. Journal of Economic Analysis and Policy 10, Issue 2 (Symposium), Article 9.

Parry, Ian W.H., Dirk Heine, Shanjun Li, and Eliza Lis, 2014a. Getting Energy Prices Right: From Principle to Practice. International Monetary Fund, Washington, DC.

Parry, Ian W.H., Chandara Veung, and Dirk Heine, 2014b. "How Much Carbon Pricing is in Countries' Own Interests? The Critical Role of Co-Benefits.” Working paper No. 4/174, International Monetary Fund, Washington, DC.

Pickrell, Don, and Paul Schimek, 1997. "Trends in Personal Motor Vehicle Ownership and Use: Evidence from the Nationwide Personal Transportation Survey.” In Proceedings from the Nationwide Personal Transportation Survey Symposium, October 29-31. No. 17 of Searching for Solutions: A Policy Discussion Series. Washington, DC: U.S. Federal Highway Administration, 85-127. 
Poterba, James M., 1991. “Is the Gasoline Tax Regressive?” In David Bradford (ed.), Tax Policy and the Economy 5. National Bureau of Economic Research, Cambridge, MA.

Rausch, S., G.E. Metcalf, and J. M. Reilly, 2011. "Distributional Impacts of Carbon Pricing: A General Equilibrium Approach with Micro-Data for Households.” Energy Economics 33: S20-S33.

Saez, Emmanuel, Joel Slemrod, and Seth H. Giertz, 2012. "The Elasticity of Taxable Income with Respect to Marginal Tax Rates: A Critical Review.” Journal of Economic Literature 50: 3-50.

Smith, Stephen, 1992. "The Distributional Consequences of Taxes on Energy and the Carbon Content of Fuels." European Economy, Special Edition No. 1: The Economics of Limiting $\mathrm{CO}_{2}$ Emissions, pp. 241-268.

Sterner, T., 2012. "Distributional Effects of Taxing Transport Fuels”. Energy Policy 41: 7583.

US IAWG, 2013. Technical Support Document: Technical Update of the Social Cost of Carbon for Regulatory Impact Analysis Under Executive Order 12866. Interagency Working Group on Social Cost of Carbon, United States Government, Washington, DC.

Walls, Margaret and Jean Hanson, 1999. "Distributional Aspects of an Environmental Tax Shift: The Case of Motor Vehicles Emissions Taxes.” National Tax Journal 52: 53-65.

Wier, Mette, Katja Birr-Pedersen, Henrik Klinge Jacobsen and Jacob Klok, 2005. “Are $\mathrm{CO}_{2}$ Taxes Regressive? Evidence from the Danish Experience.” Ecological Economics 52: 239251.

World Bank, 2014. State and Trends of Carbon Pricing. Washington, DC.

Xu, Ke, Frode Ravndal, David Evans, and Guy Carrin, 2007. "Assessing the Reliability of Household Expenditure Data: Results of the World Health Survey.” Discussion paper 5. 